\title{
Rhodamine B Detection from Inexpensive Blush On in Bandar Lampung City
}

\section{Deteksi Rhodamin B pada Perona Pipi Murah di Kota Bandar Lampung}

\author{
Rina Budi Satiyarti", Noviana Anggaraini, Iip Sugiharta \\ Universitas Islam Negeri Raden Intan Lampung \\ *E-mail: rinabudisatiyarti@ radenintan.ac.id
}

DOI : https://doi.org/10.26874/jkk.v4i1.78

Received: 30 April 2021, Revised: 30 May 2021, Accepted: 30 May 2021, Online: 31 May 2021

\begin{abstract}
Rhodamin B dye is dyes belongs to the cationic dye class which is included as a hazardous material in medicine, food, and cosmetics. Rhodamin B effect could cause growth retardation, liver damage, and defense of the cell's full immune response. This day, Rhodamin B found in food and cosmetics products. This research was conducted to detect and detremine the levels of Rhodamin B in blusher which is marketed in the largest market, namely central market in Bandar Lampung city. Blusher samples were taken from three brands. Rhodamin B dye was identified by TLC method with ethyl acetate-methanolamonia (75:30:15), detected in UV light $254 \mathrm{~nm}$ in wavelength. Concentration of Rhodamin B were calculated by UV-Vis spectrophotometry. The results showed that from 3 samples, 2 samples were contained Rhodamin B, detected from Rf $0.99 \mathrm{~cm}$ (for sample 2) and $0.95 \mathrm{~cm}$ (for sample 3) with a 0.97 $\mathrm{cm}$ standard. Rhodamin B concentration was $0.2299 \mathrm{mg} / \mathrm{g}$ for sample 2, while it was not detected in sample 3.
\end{abstract}

Keywords: blush on, Rhodamin B, UV-Vis spectrophotometry

\begin{abstract}
Abstrak
Rhodamin B adalah pewarna yang termasuk dalam golongan cationic dyes dan dinyatakan sebagai bahan berbahaya dalam obat, makanan, dan kosmetik. Rhodamin B dapat menyebabkan retardasi pertumbuhan, kerusakan hati, dan penekanan respons imun. Pewarna ini ternyata masih digunakan pada produk makanan dan kosmetika. Penelitian ini dilakukan untuk mengidentifikasi dan menentukan kadar Rhodamin B pada perona pipi yang dipasarkan di pasar terbesar, yaitu pasar tengah kota Bandar Lampung. Sampel perona pipi diambil dari tiga merek dagang yang paling laris. Identifikasi pewarna Rhodamin B dilakukan dengan metode KLT dengan etil asetat-metanol-amonia dan dideteksi di bawah sinar UV pada panjang gelombang $254 \mathrm{~nm}$. Penentuan kadar Rhodamin B ditentukan melalui metode spektrofotometri. Hasil penelitian menunjukkan dari tiga sampel perona pipi yang diteliti, dua diantaranya teridentifikasi mengandung Rhodamin B dengan Rf 0,99 cm (untuk sampel 2) dan 0,95 cm (untuk sampel 3). Kadar Rhodamin B yang terdeteksi hanya pada sampel dua, yaitu $0,23 \mathrm{mg} / \mathrm{g}$. Sedangkan untuk sampel 3 kadar Rhodamin B tidak dapat terdeteksi.
\end{abstract}

Kata kunci: Perona Pipi, Rhodamin B,Spektrofotometri UV-Vis

\section{Introduction}

Cosmetic products have variation in colour which could be based on synthetic or natural coloring agent [1]Natural coloring agent were extracted from root, leaves, and flowers of plants
[2]. While, synthetic coloring agent were formulated by mixing some chemicals [3]. Permitted color is a sample of legal coloring agent. It was two kind of agent, dye and lake. Dye is a coloring agent which had passed specification [4], 
and lake is a combination of dye and aluminium $(\mathrm{Al})$ or calcium $(\mathrm{Ca})$, then coated with $\mathrm{Al}(\mathrm{OH})_{3}$ [5]. Recently, industries prefer to utilize synthetic dye as replacement of natural dye. It is because the characteristic of synthetic dye more stable, not adding flavour, economic, and intense [6].

Food and Drug Administration (FDA) had prohibited rhodamie $\mathrm{B}$ as a dye. Because rhodamine B is tending to be carcinogenic [6]. Rhodamine B is a member of xanthene dye family. Whereas the characteristic of this dye agent is it has an alkyl in its structure $\left(\mathrm{CH}_{3}-\mathrm{CH}_{3}\right)$ [7], and it is also toxic, coming from chlorine $(\mathrm{Cl})$. The main structure of rhodamine $\mathrm{B}$ is hydrocarbon poly aromatic (PAH). Rhodamine B could be active radical compound when it was activated by cytochrome P-50 enzyme. This radical molecule more likely connect with protein, fat, and DNA [8].

The toxicity of rhodamine B pursue growth retardation, liver damage, erythrocyte haemolysis, and immune pressure in lymphatic cell. Whether it was no epidemiology data which showed the carcinogenicity level of rhodamine $\mathrm{B}$, some research showed that rhodamine $\mathrm{B}$ is a mutagenic agent and given a local sarcoma to the mice [9]. Some cosmetic merchant in Pasar Tengah, the largest market in Bandar Lampung sell some blush on from several cosmetic brands. This research analyzes rhodamine B composition from three cheapest blush on that sold in Pasar Tengah market, whereas the consumer is under 25 years old.

\section{Method}

Materials are chloric acid 4N, natrium sulphate anhydrate, rhodamine B BPFI, ammonia, ethyl acetate, and methanol. Sample was blush on from tree different brand, and there was the lowest price.

For about $500 \mathrm{mg}$ samples were diluted into chloric acid $4 \mathrm{~N} 2 \mathrm{~mL}$ and methanol $8 \mathrm{~mL}$, to make homogenous mixture we were using vortex. Then, the mixtures were filtered.

Rhodamine B was detected using thin layer chromatography using silica gel. Eluents were ethyl acetate-methanol-ammonia (75:30:15). Rhodamine B visualized at $254 \mathrm{~nm}$ wavelength. Concentration of rhodamine B were determined by spectrophotometry method using UV-Vis spectrophotometer type 1800 setting on 560.45 $\mathrm{nm}$ in wavelength.

\section{Result and Discussion}

\subsection{Qualitative analysis}

The result of color detection on silica plate showed that sample 2 and 3 contain rhodamine B (figure 1). The color was detected as yellow color after rhodamine B get fluorescence by UV light. The changes of color were caused by UV light absorbed in short wavelength.

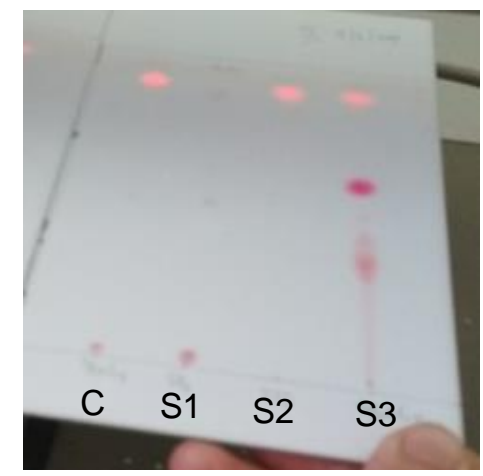

Figure 1. Visualization of TLC samples Left to right: Control (C); Sample 1 (S1); Sample 2 (S2); Sample 3 (S3)

Further analysis was retention time $\left(\mathrm{R}_{f}\right)$ calculation. It is needed to convince the characteristic of all samples as same as standard. The $\mathrm{R}_{f}$ were shown in Table 1 .

The $\mathrm{R}_{f}$ analysis of all samples showed that sample 1 has $\mathrm{R}_{f}$ number 0.45 . While others have $\mathrm{R}_{f}$ number 0.99 and 0.95 . Fluorescence result showed that sample 2 and 3 were at the same color, which is pink. It is a proven that sample 2 and 3 may contain rhodamine $B$.

\subsection{Quantitative analysis}

Calibration curve were made to calculate rhodamine B concentration from samples (figure 2 ). As a standard we used rhodamine $B$. The range concentration of standard was $0 \mathrm{ppm}$ to $10 \mathrm{ppm}$. Based on quantitative analysis, concentration of sample 3 is $0.23 \mathrm{mg} / \mathrm{g}$ (table 1), while other samples the concentration were too low. Nevertheless, all samples contain rhodamine B.

As shown from qualitative and quantitative result, sample no. 3 positive contain Rhodamine B. It clearly has pink fluorescence in visual that brighter than sample no.2. It is also having $\mathrm{Rf}$ 0.95 , close to control. According to SNI 01-28951992 [10]. For Rhodamine B analysis using TLC resulting $\mathrm{R}_{f} 1$ is positive contain Rhodamine $\mathrm{B}$. Each sample no. 2 and sample no. 3 has $\mathrm{R}_{f}$ closely to 1 . Therefore, we need quantification analysis. There is only sample no. 3 could be quantified, 
though is very low concentration. Nevertheless, utilization of Rhodamine B as dye is prohibited in Indonesia.

Prohibition of rhodamin B as dye agent had been arranged by Indonesian food and drug control agency. It was clearly stated that (1) Cosmetic ingredients must fulfil quality requirements from Indonesian cosmetic codes or another standard which had acknowledgement by law, (2) Cosmetic ingredients mentioned in (1) can be used in cosmetic fabrication.

Besides cosmetic ingredient which is mentioned in point (1) and (2), specific ingredients prohibit to use, accordance to Indonesian National Agency of Drug and Food Control No.18 year 2015 about prohibited cosmetic ingredients. Also, utilization Rhodamine B as dye agent can harm human body [11]. Because it will release free chlorin to body, and alkylated compound $\mathrm{CH}_{3-}$ $\mathrm{CH}_{3}$ which is a free radical. Therefore, General Director of Supervision of Indonesian National Agency of Drug and Food Control had declared that Rhodamine $\mathrm{B}$ is prohibited to use as coloring agent (No.00386/C/SK/II/90) [12].

Table 1. Qualitative Rhodamine B Analysis

\begin{tabular}{cccccc}
\hline Code & Visual & $\begin{array}{c}\text { UV 254 } \\
\text { (Flouresence) }\end{array}$ & $\mathbf{R}_{f}(\mathbf{c m})$ & $\begin{array}{c}\text { Rhodamine } \\
\text { standard } \\
(\mathbf{c m})\end{array}$ & Result \\
\hline C & Pink & + & 0,97 & 0,97 & - \\
S1 & Orange & - & 0,45 & 0,97 & Negative \\
S2 & Pink & + & 0,99 & 0,97 & Positive \\
S3 & Pink & + & 0,95 & 0,97 & Positive \\
\hline
\end{tabular}

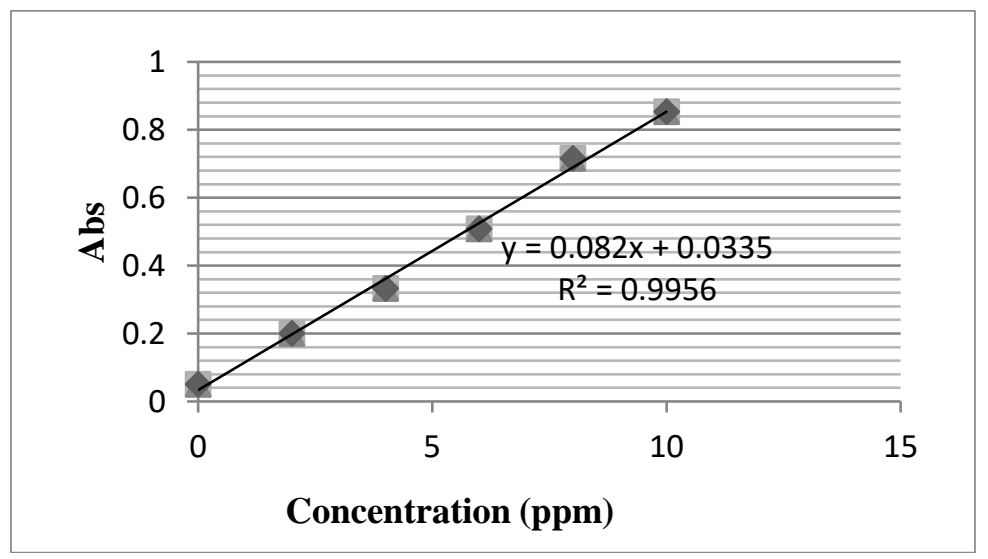

Figure 2. Standard Curve of rhodamine B

\section{Conclusion}

There were two cheap blush on from qualitative analysis are contain rhodamine $\mathrm{B}$. as it shown as sample 2 and sample 3 . Rhodamin B as dye agent are prohibit, it is referring to Indonesian National Agency of Drug and Food Control regulation and SNI 01-2895-1992.

\section{References}

[1]. Hasanah AN, Musfiroh I, Saptarini NM, Rahayu D. Identifikasi Rhodamin B pada Produk Pangan dan Kosmetik yang Beredar di Bandung. J Ilmu Kefarmasian Indones. 2014;12(1):104-9.
[2]. Afriyeni H, Utari NW. Identifikasi Zat Warna Rhodamin B pada Lipstik Berwarna Merah yang Beredar di Pasar Raya Padang. J Farm Higea. 2016;8(1):59-64.

[3]. Purniati NK, Ratman R, Jura MR. Identifikasi Zat Warna Rhodamin B Pada Lipstik yang Beredar di Pasar Kota Palu. J Akad Kim. 2015;4(3):155-60.

[4]. Nugraheni M. Pewarna Alami: Sumber dan Aplikasinya pada Makanan dan Kesehatan. Yogyakarta: Graha Ilmu; 2014.

[5]. Fachruddin L. Memilih Dan Memanfaatkan Bahan Tambahan Makanan. Bogor: PT Tribus Agriwidya. 
[6]. Rajapaksha GKM, Wansapala MAJ, Silva ABG. Detection of Synthetic Colours in Selected Foods \& Beverages Available in Colombo District, Sri Lanka. Int J Sci Res. 2015;6(5):801-8.

[7]. Wang C, Masi A, Fernandez L. On-line micellar-enhanced spectrofluorimetric determination of rhodamine dye in cosmetics. Talanta. 2007; Available from: http://dx.doi.org/10.1016/j.talanta.2007.10. 041

[8]. Anjasmara PA, Romdhoni MF, Purbowati MR. Pengaruh Pemberian Rhodamin B Peroral Subakut Terhadap Perubahan Ketinggian Mukosa Gaster Tikus Putih Galur Wistar (Rattus norvegicus Strain Wistar). Saintika Med [Internet]. 2018;13(2):58. Available from: http://dx.doi.org/10.22219/sm.v13i2.5225
[9]. Kaji T, Kawashima T, Sakamoto M, Kurashige Y, Koizumi F. Inhibitory effect of rhodamine $\mathrm{B}$ on the proliferation of human lip fibroblasts in culture. Toxicology [Internet]. 1991;68(1):11-20. Available from: http://dx.doi.org/10.1016/0300483x(91)90058-9

[10]. SNI. Cara Uji Pewarna Tambahan Makanan SNI 01-285-1992. SNI; 01-285-1992, 1992.

[11]. Badan Pengawas Obat dan Makanan. Peraturan Persyaratan Teknis Bahan Kosmetika. Indonesia: BPOM; 18, 2015.

[12]. Direktur Jenderal Pengawasan Obat dan Makanan. Zat Warna Tertentu yang Dinyatakan Sebagai bahan Berbahaya dalam Obat, Makanan dan Kosmetika. BPOM; 00386/C/SK/II/90, 1990. 